\title{
Effect of Chloramphenicol on Rabbit Doe Fertility and Prenatal Development
}

\author{
Ngoula Ferdinand*, Tsafack Borice, Tadondjou Tchingo Cyrille D’Alex, Ngoumtsop Victor Herman, Vemo \\ Narcisse Bertin and Tchoumboue Joseph \\ Animal Physiology and Health Research Unit, Department of Animal Science, FASA, University of Dschang, Cameroon \\ *Corresponding author email: fngoula@yahoo.fr
}

\begin{abstract}
The study examined 24 nulliparous, sexually mature female rabbits (6 months) divided into 4 groups of 6 does each, comparable in terms of body weight. To each group was randomly attributed by gavage 25,50 and $75 \mathrm{mg}$ of $\mathrm{CP} / \mathrm{kg}$ of body weight 30 days before mating (6 females for 1 male) and during the whole gestation period. After sacrifice of the does on the 28th day post-coitum, the organs (ovaries, liver, and kidneys) and fetus were collected and examined to detect eventual anomalies. The main results showed a nonsignificant increase of relative weight of liver and kidneys and decrease of the ovaries. The rate of fetal mortality and of viability were not significantly affected by CP dose. A decreasing dependent dose of the average litter size, the average litter weight, the placenta and the gravid uterus, the number of placenta and the implantation sites were registered. The only anomaly registered was the insufficient fusion of the cranial bones at the dose 50 and $75 \mathrm{mg} / \mathrm{kg}$ of CP. A significant decrease of the level of proteins in the serum and ovaries were noted in animals treated in relation to those of the control group. It was concluded that $\mathrm{CP}$ administered at doses of 25,50 and $75 \mathrm{mg} / \mathrm{kg}$ BW to pre and post-coital rabbit does negatively affected fertility but had no significant teratogenic effects. CP should therefore be limited or prohibited in husbandry.
\end{abstract}

Keywords: chloramphenicol, rabbit doe, toxicity, teratogenicity, fertility

\section{Introduction}

Antibiotics have long been used to improve animal productivity. In fact, they are the most common registered drugs used in animal farms (Saba et al., 2000). Antibiotics are used in human and veterinary medicine to treat and prevent diseases, and as growth promoters (Ian et al., 2004; FAO/WHO, 2012). However, the extensive use of antibiotics may result in adverse consequences (Ian et al., 2004). For example, the unmethodical use of antibiotics in animal production, without any veterinary prescription and supervision, may lead to antibiotics resistance or toxic effects (Dang et al., 2013). Antibiotics-related toxicity and side effects are well documented. For instance, nephrotoxicity is a well-known complication of tetracycline, sulphonamides, B-lactams or aminoglycosides; hepatotoxicity is a complication of rifampicin; intestinal disorders are complications of macrolides, lincosamides; bone alterations are complications of quinolones, fluoroquinolone, etracycline or chloramphenicol. Antibiotic toxicity has also been reported on reproduction system (Wollenberger et al., 2000).

Chloramphenicol is one of the most used veterinary antibiotics against staphylococci, streptococci, Bordella bronchiseptica, Escherichia coli and salmonella species (Nouws et al., 1986). Following oral or parental administration, chloramphenicol is rapidly absorbed and distributed throughout the organs and tissues. Its residues and metabolites are found in all edible tissues and in milk and eggs (Milhaud, 1985). However, chloramphenicol has been reported to be very toxic and even fatal at acute overdose. In fact, several studies established that chloramphenicol inhibits protein synthesis in bacteria by binding reversibly to the $50 \mathrm{~S}$ ribosomal subunit at the peptidyl transferase site and inhibits the transpeptidation reaction. It can also inhibit mitochondrial protein synthesis in mammalian cells, or cause 
mitochondrial DNA damage and carcinogenicity (Ada, 2007 and Stouten, 2011). Moreover, chloramphenicol can readily cross the placental barrier and affect embryos /fetal development (Wangikar et al., 2005 and Stouten, 2011). CP (200 or $300 \mathrm{mg} / \mathrm{rat}$ ) administered in rat's diet during gestational days 0-20, Macker et al. (1975) had increased the resorptions, reduced the fetal and placental weights, as well as the numbers of live fetus at both doses. After $500-$ $2000 \mathrm{mg} / \mathrm{kg}$ BW CP gavage to rats and mice, and 500 and $1000 \mathrm{mg} / \mathrm{kg}$ BW to rabbits for one or more days during gestation, Fritz and Hess (1975) observed a significant increase of embryonic/foetal death percentage. They also noted an increase of anomalies such as omphalocele or umbilical hernia in combination with costal fusion, a retarded skeletal development at doses 1000 and $2000 \mathrm{mg} / \mathrm{kg}$ BW.

However, previous studies administered high, but not maternally toxic, oral doses of $\mathrm{CP}$ $(500-2000 \mathrm{mg} / \mathrm{kg} \mathrm{BW})$ during gestational days 0-20 to rats, or during selected gestational day(s) to rats, mice or rabbits; while lower doses $(25-200 \mathrm{mg} / \mathrm{kg} \mathrm{BW}$ ) were given orally to mice during the third stage of gestation and to rats, during days 7 - 21 (Stouten, 2011).

Although teratogen effects of high doses of $\mathrm{CP}$ are documented, this antibiotic is still largely used in developing countries at small doses (Saba et al., 2000). This work aimed to evaluate the sub chronic toxicity of low doses of CP on gestational rabbit and on embryo/fetal development.

\section{Materials and Methods}

\section{Study area}

The study was conducted at the Teaching and Research Farm of the University of Dschang, located in the Sudano-Guinean zone (latitude: $5-7^{\circ} \mathrm{N}$, longitude: $18-20^{\circ} \mathrm{E}$; altitude $1500 \mathrm{~m}$ ). The average temperature is $20^{\circ} \mathrm{C}$ and the relative humidity is generally between 80 and $98 \%$. The average annual rainfall is 2000 $\mathrm{mm}$.

\section{Experimental animals and their feeding}

For this work, 24 sexually mature female rabbits, (6 months), weighing $2.8-3.0 \mathrm{~kg}$, all from the Teaching and Research Farm (University of Dschang, Cameroon) were used. Throughout the experimental period, feed and water were given ad libitum. All rabbits were provided with the same basal diet containing $18.078 \%$ crude protein, $2435.64 \mathrm{kcal} / \mathrm{kg}$ metabolizable energy and $12.02 \%$ crude fiber.

\section{Chloramphenicol preparation}

Chloramphenicol palmitate $250 \mathrm{mg}$ was purchased from a pharmacy. Before use, the tablets were dissolved in distilled water and given at doses 25,50 and $75 \mathrm{mg} / \mathrm{kg}$ BW.

\section{Ethical consideration}

Experimental protocols used in this study strictly conformed with the internationally accepted standard ethical guidelines for laboratory animal use and care as described in the European Community guidelines; EEC Directive $86 / 609 / E E C$, of the $24^{\text {th }}$ November 1986 (EEC., 1986).

\section{Experimental design}

Before starting the experiment, the animals were weighed and divided into 4 groups of 6 female rabbits each, comparable in terms of weight. After 2 weeks of acclimation, oral gavage was given to control group: distilled water, group 1:25 $\mathrm{mg} / \mathrm{kg} \quad B W$ of chloramphenicol, group $2: 50 \mathrm{mg} / \mathrm{kg}$ BW of chloramphenicol and group $3: 75 \mathrm{mg} / \mathrm{kg}$ BW of chloramphenicol.

After 30 days of treatment, non-treated and sexually mature male rabbits were introduced in each group. Treatment were pursued during pregnancy and female rabbits were sacrificed at the $28^{\text {th }}$ day post coïtum. The effects of chloramphenicol on fertility and embryos/fetus development were evaluated. 
Ngoula Ferdinand et al/Animal Production. 21(1):1-9, 2019

Accredited by Kemenristek Dikti No 32a/E/KPT/2017. ISSN 1411-2027

Sacrifice of rabbits, serum and organs collection

At the end of treatment $\left(28^{\text {th }}\right.$ day post coïtum), rabbits were anesthetized (intraperitonial injection of diazepam $10 \mathrm{mg} / \mathrm{kg}$ BW and Ketamine $50 \mathrm{mg} / \mathrm{kg}$ BW) and blood collected by cardiac puncture in dry tubes. Serum was then isolated and stored at $-20^{\circ} \mathrm{C}$ for biochemical estimation of proteins.

After sacrifice by decapitation, the abdominal cavity and inguinal sac were opened, and organs like liver, kidney, heart, ovaries, gravid uterus, placenta and fetus were carefully removed, freed of adipose tissue, blotted dry and weighed separately. The ovaries were then homogenized in a known volume of $0.9 \% \mathrm{NaCl}$ solution to obtain a $15 \%$ homogenate. The resulting homogenate was centrifuged at 3,000 rpm for $30 \mathrm{~min}$ at $4^{\circ} \mathrm{C}$ and aliquots of supernatant were kept at $-20^{\circ} \mathrm{C}$ for biochemical estimation of proteins.

\section{Evaluation of serum and ovular proteins}

Biochemical assays were performed as described by Bradford (1976) for ovular proteins; Gornal et al. (1949) for blood proteins.

\section{Embryo-toxicity and teratogenicity assay}

After weighting, gravid uterus was opened and the following parameters were determined: number of yolk and implantation site, sex ratio, number of total, pre and post implantation loss (Waalkens-berendsen et al., 1998), fetus viability and mortality, head, tail and total fetus length. To confirm pre implantation resorption, uterus was placed in a $2 \%$ sodium hydroxide solution for 10 minutes as described by Yamada et $a l$. (1985). Toxic and teratogenic effects were examined on fetus immerged in a $70^{\circ} \mathrm{C}$ water for 30 seconds. Malformation of head, tail and heart, scoliosis, growth retardation and other skeletal abnormalities were evaluated. Skeletal abnormalities were evaluated after fetus fixation in 95\% ethanol then coloration with red Alizarine as described by Jeong-Sup (2012). Other parameters including gestational index and prolificacy index were also determined.

\section{Statistical analyses}

Data were submitted to one-way analysis of variance at $P<0.05$. When differences were significant between means, the latter were separated using the Duncan test. Pearson correlation coefficient between parameters was also performed at $P<0.05$. Chi square test $(X 2)$ and software R Gue 3.02 were used to analyze data expressed in percentage. The analyses were performed using SPSS version 20.0.

\section{Results and Discussions}

Effects of chloramphenicol on some growth parameters of female rabbits

Female rabbit body weight gain, food and water consumption recorded during the two periods of treatment are summarized in Table 1. Their weekly evolution is represented individually in Figures 1, 2 and 3.

Table 1 indicate that during the two periods of treatment, chloramphenicol did not affect significantly the body weight gain, food and water consumption. Irrespective of the treatment, food consumption decreased nonsignificantly with time during the first 30 days of treatment (on non-pregnant females) (Figure 1A). A dose dependant and non-significant decrease of food consumption was recorded in pregnant females exposed to chloramphenicol (Figure 1B). On the other hand, in non-treated (control) and in the group treated with 25 $\mathrm{mg} / \mathrm{kg}$ BW, food consumption increased during the first week before decreasing between weeks 2 to 4 . 
Ngoula Ferdinand et al/Animal Production. 21(1):1-9, 2019

Accredited by Kemenristek Dikti No 32a/E/KPT/2017. ISSN 1411-2027

Table 1. Effects of CP on food and water consumption and body weight gain in female rabbits

\begin{tabular}{|c|c|c|c|c|}
\hline \multirow{2}{*}{$\begin{array}{l}\text { Experimental } \\
\text { Period }\end{array}$} & \multirow{2}{*}{$\begin{array}{l}\text { Doses of } \\
\text { Chloramphenicol } \\
(\mathrm{mg} / \mathrm{kg} \mathrm{BW})\end{array}$} & \multicolumn{3}{|c|}{ Parameters } \\
\hline & & $\begin{array}{l}\text { Food consumption } \\
(\mathrm{g})\end{array}$ & $\begin{array}{c}\text { Water consumption } \\
(\mathrm{ml})\end{array}$ & $\begin{array}{c}\text { Body weight gain } \\
\text { (g) }\end{array}$ \\
\hline \multirow{4}{*}{$\begin{array}{l}\text { Non-pregnant } \\
\text { female rabbits (first } \\
30 \text { days of } \\
\text { treatment) }\end{array}$} & 0 (Control) & $1025.00 \pm 184.42^{a}$ & $1557.93 \pm 197.49^{a}$ & $71.81 \pm 36.60^{\mathrm{a}}$ \\
\hline & 25 & $1026.06 \pm 128.13^{a}$ & $656.25 \pm 421.83^{a}$ & $71.06 \pm 33.17^{a}$ \\
\hline & 50 & $925.93 \pm 56.52^{a}$ & $1720.18 \pm 303.23^{a}$ & $50.68 \pm 20.04^{a}$ \\
\hline & 75 & $1003.50 \pm 90.52^{\mathrm{a}}$ & $1953.62 \pm 327.83^{\mathrm{a}}$ & $73.25 \pm 58.42^{\mathrm{a}}$ \\
\hline \multirow{4}{*}{$\begin{array}{l}\text { Pregnant female } \\
\text { rabbits ( } 28 \text { days of } \\
\text { treatment) }\end{array}$} & 0 (control) & $802.87 \pm 109.12^{\mathrm{a}}$ & $1765.93 \pm 189.15^{a}$ & $115.87 \pm 44.64^{a}$ \\
\hline & 25 & $757.18 \pm 134.87^{a}$ & $1974.68 \pm 707.07^{a}$ & $54.62 \pm 37.39^{a}$ \\
\hline & 50 & $893.31 \pm 80.64^{a}$ & $2332.31 \pm 575.60^{\mathrm{a}}$ & $101.12 \pm 10.33^{a}$ \\
\hline & 75 & $762.12 \pm 130.82^{\mathrm{a}}$ & $2393.12 \pm 301.35^{a}$ & $88.31 \pm 45.78^{a}$ \\
\hline
\end{tabular}

$\mathrm{n}=$ number of rabbit; $(\mathrm{a}, \mathrm{b})$ on the same line, values affected by the same letter are not significantly different; data were expressed as mean \pm standard deviation
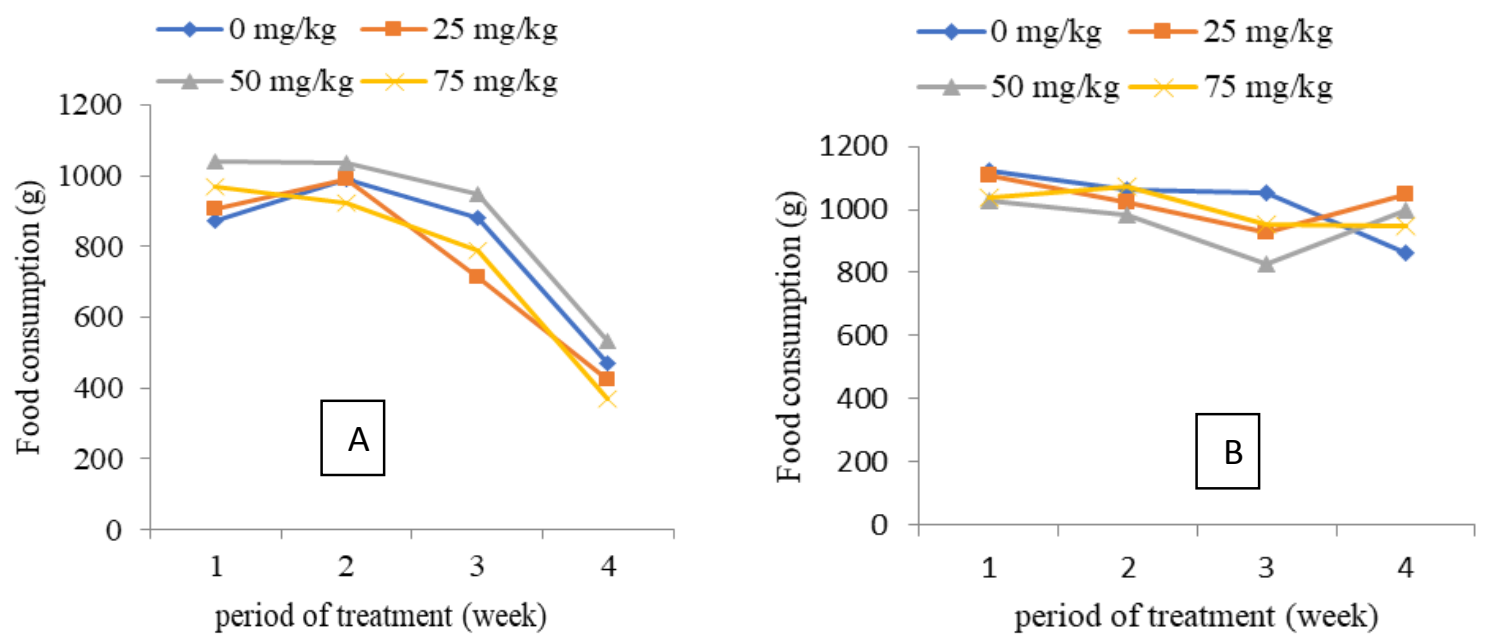

Figure 1. Weekly evolution of food consumption in non-pregnant $(A)$ and pregnant $(B)$ female rabbits treated with $\mathrm{CP}$

During the first three weeks, water consumption regularly but non-significantly decreased (Figure 2A). On the contrary, water consumption increased non-significantly between the third to fourth weeks. However, water consumption in global was higher in female rabbit receiving the highest dose of $\mathrm{CP}$ (75 mg/kg BW). In pregnant does, water consumption decreased non-significantly with time irrespective of treatment. No significant difference was found between groups for water consumption (Figure 2B). However, water consumption was more important in female rabbit receiving 50 and $75 \mathrm{mg} / \mathrm{kg} \mathrm{BW}$ of $\mathrm{CP}$.
Irrespective of the treatment, BW gain increased significantly between the first and second week of treatment before decreasing significantly between the second and third week (Figure 3). However, between the third and fourth week, body weight gain seemed to stabilize in treated group while it continued decreasing in control group. After the females became pregnant, BW gain increased throughout the gestational period in nontreated group. On the contrary, in group treated with 25 and $50 \mathrm{mg} / \mathrm{kg} \mathrm{BW}, \mathrm{BW}$ gain increased only between week 1 and 2 before decreasing for the remaining treatment time. 
Ngoula Ferdinand et al/Animal Production. 21(1):1-9, 2019

Accredited by Kemenristek Dikti No 32a/E/KPT/2017. ISSN 1411-2027
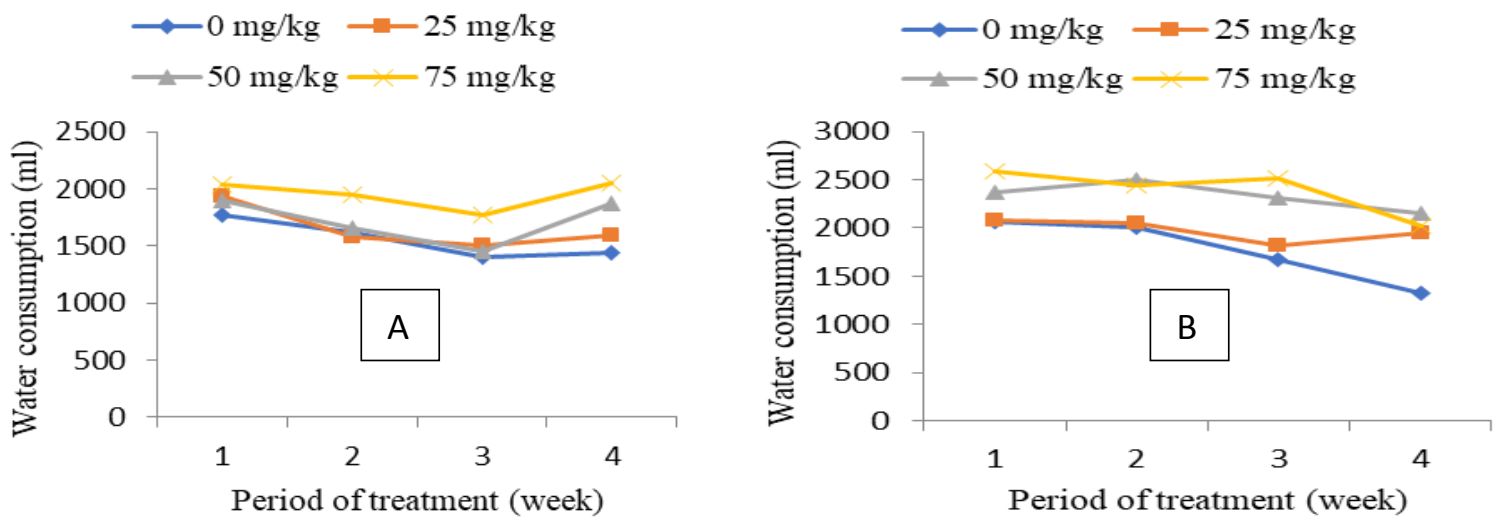

Figure 2. Weekly evolution of water consumption in non-pregnant (A) and pregnant (B) female rabbits treated with $\mathrm{CP}$
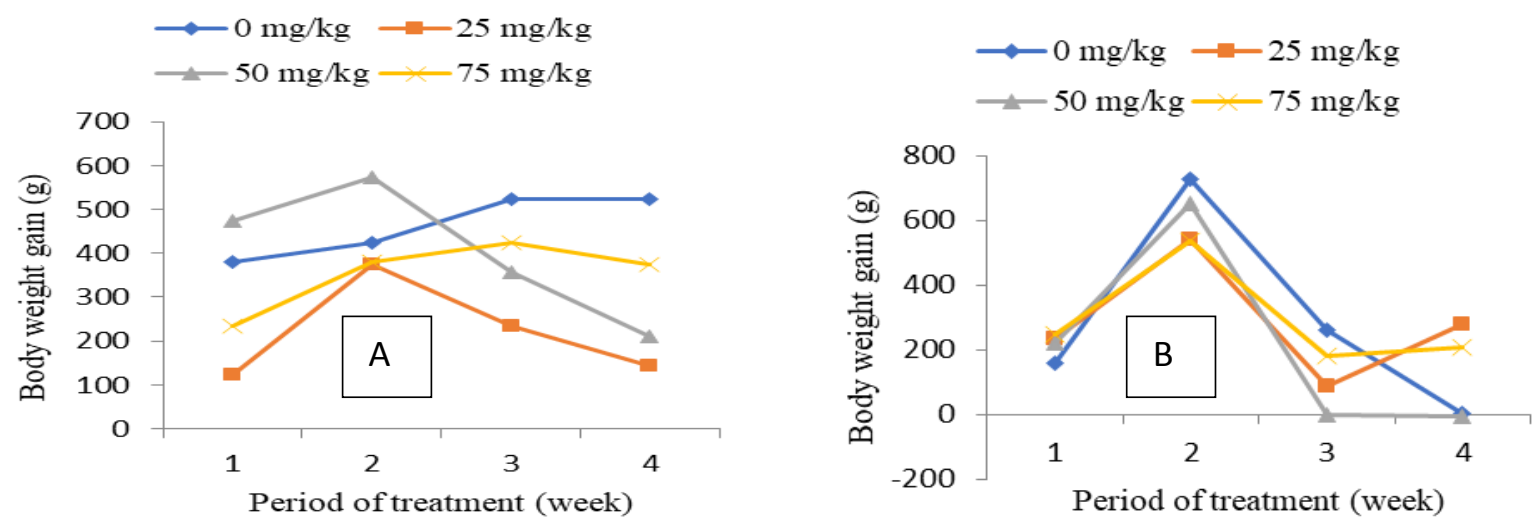

Figure 3. Weekly evolution of body weight gain in non-pregnant (A) and pregnant (B) female rabbits treated with $\mathrm{CP}$

Effects of chloramphenicol on some reproductive parameters of gravid rabbit does

The effects of chloramphenicol on reproductive parameters of gravid rabbit does are summarized in Table 2. The percentage of female rabbits in oestrus, gestational index, viability rate at birth and abortion rate were not affected by $\mathrm{CP}$ treatment. On the contrary, fertility index decreased at the highest dose of $\mathrm{CP}(75 \mathrm{mg} / \mathrm{kg} \mathrm{BW})$. In general, the gravid uterus weight, the weight and size of litter, weight of ovaries and prolificacy index decreased dose dependently. However, only the values of gravid uterus weight, the weight and size of litter obtained in female rabbits treated with the highest dose of CP (75 mg/kg BW) were significantly lower $(\mathrm{P}<0.05)$ as compared to the value recorded in non-treated female rabbit Effects of Chloramphenicol on blood and ovaries protein level.

Table 3 summarize the effects of chloramphenicol on protein level in blood and ovaries. The total protein level in serum was significantly lower $(P<0.05)$ in treated group as compared to control group. In treated group, the value obtained with the highest dose (75 $\mathrm{mg} / \mathrm{kg} \mathrm{BW}$ ) was significantly lower than those obtained with 25 and $50 \mathrm{mg} / \mathrm{kg}$ BW. In the ovaries, total protein level was significantly decreased $(P<0.05)$ with the highest dose of $C P$ (75 mg/kg BW). 
Ngoula Ferdinand et al/Animal Production. 21(1):1-9, 2019

Accredited by Kemenristek Dikti No 32a/E/KPT/2017. ISSN 1411-2027

Table 2. Effects of chloramphenicol on some reproductive parameters of gravid rabbits does

\begin{tabular}{lllll}
\hline & \multicolumn{4}{l}{ Doses of chloramphenicol $(\mathrm{mg} / \mathrm{kg} \mathrm{BW})$} \\
\cline { 2 - 5 } Parameters & $\begin{array}{l}\text { Control }(0) \\
(\mathrm{n}=6)\end{array}$ & $\begin{array}{c}25 \\
(\mathrm{n}=6)\end{array}$ & $\begin{array}{c}50 \\
(\mathrm{n}=6)\end{array}$ & $\begin{array}{c}\mathrm{n}=6) \\
(\mathrm{n}=6)\end{array}$ \\
\hline Percentage of female in oestrus & $100 \pm 00^{\mathrm{a}}$ & $100 \pm 00^{\mathrm{a}}$ & $100 \pm 00^{\mathrm{a}}$ & $100 \pm 00^{\mathrm{a}}$ \\
Fertility Index (\%) & $100 \pm 00^{\mathrm{a}}$ & $100 \pm 00^{\mathrm{a}}$ & $100 \pm 00^{\mathrm{a}}$ & $83.33 \pm 00^{\mathrm{b}}$ \\
Gestational Index (\%) & $100 \pm 00^{\mathrm{a}}$ & $100 \pm 00^{\mathrm{a}}$ & $100 \pm 00^{\mathrm{a}}$ & $100 \pm 00^{\mathrm{a}}$ \\
Gravid uterus weight (g) & $403.00 \pm 147.85^{\mathrm{a}}$ & $328.07 \pm 29.66^{\mathrm{ab}}$ & $364.25 \pm 24.71^{\mathrm{ab}}$ & $250.75 \pm 92.84^{\mathrm{b}}$ \\
Litter weight (g) & $261.86 \pm 87.57^{\mathrm{a}}$ & $227.68 \pm 13.63^{\mathrm{ab}}$ & $240.23 \pm 23.22^{\mathrm{ab}}$ & $157.31 \pm 61.93^{\mathrm{b}}$ \\
Size of litter & $8.75 \pm 3.20^{\mathrm{a}}$ & $7.50 \pm 0.57^{\mathrm{ab}}$ & $7.00 \pm 1.4^{\mathrm{a}}$ & $5.25 \pm 2.21^{\mathrm{b}}$ \\
Viability rate at birth (\%) & $100 \pm 00^{\mathrm{a}}$ & $100 \pm 00^{\mathrm{a}}$ & $100 \pm 00^{\mathrm{a}}$ & $100 \pm 00^{\mathrm{a}}$ \\
Abortion rate (\%) & $00 \pm 00^{\mathrm{a}}$ & $00 \pm 00^{\mathrm{a}}$ & $00 \pm 00^{\mathrm{a}}$ & $00 \pm 00^{\mathrm{a}}$ \\
Weight of ovaries (g) & $0,15 \pm 0,004^{\mathrm{a}}$ & $0,13 \pm 0,01^{\mathrm{a}}$ & $0,14 \pm 0,002^{\mathrm{a}}$ & $0,11 \pm 0,110^{\mathrm{a}}$ \\
Prolificacy Index (\%) & $875 \pm 320.15^{\mathrm{a}}$ & $750 \pm 570.73^{\mathrm{a}}$ & $700 \pm 141.42^{\mathrm{a}}$ & $525 \pm 221.73^{\mathrm{a}}$
\end{tabular}

$\mathrm{n}=$ number of rabbit; $(\mathrm{a}, \mathrm{b})$ on the same line, values affected by the same letter are not significantly different ; data were expressed as mean \pm standard deviation

Table 3. Effects of chloramphenicol on serum and ovular protein level

\begin{tabular}{|c|c|c|c|c|}
\hline \multirow{2}{*}{ Protein level } & \multicolumn{3}{|c|}{ Doses of chloramphenicol (mg/kg pc) } & \multirow[b]{2}{*}{75} \\
\hline & 0 (Control) & 25 & 50 & \\
\hline Serum $(\mathrm{mg} / \mathrm{ml})$ & $54.75 \pm 0.35^{\mathrm{a}}$ & $46.75 \pm 0.50^{b}$ & $46.75 \pm 0.25^{b}$ & $34.00 \pm 4.00^{c}$ \\
\hline ovaries ( $\mu \mathrm{g} / \mathrm{g})$ & $1044.00 \pm 49.7^{a}$ & $1057.00 \pm 36.77^{a}$ & $1024.50 \pm 57.6^{a}$ & $797.00 \pm 42.45^{b}$ \\
\hline
\end{tabular}

$\mathrm{n}=$ number of rabbit; $(\mathrm{a}, \mathrm{b})$ on the same line, values affected by the same letter are not significantly different; data were expressed as mean \pm standard deviation

\section{Embryo and teratogenic toxicity of chloram- phenicol}

The effects of chloramphenicol (CP) on embryo/fetus growth and development are summarized in Table 4. The number of corpora lutea per female rabbit, number of post implantation resorptions, fetal weight and length, fetal tail length, fetal head length, crown rump length nor sex ratio were not significantly affected by CP treatment. However, the total number of resorptions and number of pre-implantation resorptions obtained in female rabbits treated with the highest dose of CP $(75 \mathrm{mg} / \mathrm{kg}$ BW) were significantly higher $(P<0.05)$ than the value registered in the other groups. The external observation of fetus did not show any major skeletal abnormalities. However, fusion between cranial bones was not tight enough in the fetuse of female rabbits treated with 50 $\mathrm{mg} / \mathrm{kg} \mathrm{BW}$ and $75 \mathrm{mg} / \mathrm{kg}$ BW. Although the toxicity of high doses of chloramphenicol have been documented, this antibiotic is still used (Saba et al., 2000). In this study, we evaluated the toxicity of small doses of chloramphenicol.

The treatment of female rabbits with $\mathrm{CP}$ reduced dose dependently but non significantly feed consumption. This finding supported Mackler et al. (1975) in pregnant rats treated with CP (200 and $300 \mathrm{mg} / \mathrm{kg}$ of body weight). In fact, it is well established that CP can be metabolized by intestinal bacteria to produce dehydro-chloramphenicol. This metabolite could trigger nausea and anorexia that subsequently decreased feed consumption. This reduction partly explained the reduction of the body weight observed in non pregnant and pregnant rabbits (Ada, 2007). A positive and significant correlation $(r=0.68 ; \mathrm{P}<0.05)$ was found between feed consumption and body weight gain. 
Ngoula Ferdinand et al/Animal Production. 21(1):1-9, 2019

Accredited by Kemenristek Dikti No 32a/E/KPT/2017. ISSN 1411-2027

Table 4. Embryotoxicity of chloramphenicol after female rabbit treatment

\begin{tabular}{|c|c|c|c|c|}
\hline \multirow{2}{*}{ Parameters } & \multicolumn{4}{|c|}{ Doses of chloramphenicol (mg/kg BW) } \\
\hline & $\begin{array}{l}0 \text { (Control) } \\
(n=6)\end{array}$ & $\begin{array}{l}25 \\
(n=6)\end{array}$ & $\begin{array}{l}50 \\
(n=6)\end{array}$ & $\begin{array}{l}75 \\
(n=6)\end{array}$ \\
\hline Total corpora lutea/rabbit & $9.75 \pm 3.20^{\mathrm{a}}$ & $8.50 \pm 0.57^{\mathrm{a}}$ & $8.50 \pm 1.29^{\mathrm{a}}$ & $9.00 \pm 1.63^{\mathrm{a}}$ \\
\hline Total placenta & $8.75 \pm 3.20^{\mathrm{a}}$ & $7.50 \pm 0.57^{\mathrm{ab}}$ & $7.00 \pm 1.4^{\mathrm{ab}}$ & $5.25 \pm 2.21^{b}$ \\
\hline Total implantation site & $9.00 \pm 2.94^{\mathrm{a}}$ & $7.50 \pm 0.57^{\mathrm{ab}}$ & $7.00 \pm 1.41^{\mathrm{ab}}$ & $5.25 \pm 2.21^{b}$ \\
\hline Total resorption & $1.00 \pm 0.0^{\mathrm{b}}$ & $1.00 \pm 0.81^{b}$ & $1.50 \pm 1.29^{b}$ & $3.50 \pm 2.82^{a}$ \\
\hline Total resorption pre-imp & $1.00 \pm 0.0^{\mathrm{b}}$ & $0.75 \pm 0.95^{b}$ & $1.25 \pm 0.50^{\mathrm{b}}$ & $3.50 \pm 2.08^{a}$ \\
\hline Total resorption post-imp & $00 \pm 0.0^{\mathrm{a}}$ & $0.25 \pm 0.50^{\mathrm{a}}$ & $0.25 \pm 0.50^{\mathrm{a}}$ & $0.0 \pm 0.0^{\mathrm{a}}$ \\
\hline Total pre-imp resorption & $1.00 \pm 0.0^{\mathrm{b}}$ & $0.75 \pm 0.95^{b}$ & $1.25 \pm 1.5^{b}$ & $3.50 \pm 2.08^{a}$ \\
\hline Total post-imp resorption & $0.0 \pm 0.0^{\mathrm{a}}$ & $0.25 \pm 0.50^{\mathrm{a}}$ & $0.25 \pm 0.50^{a}$ & $0.0 \pm 0.0^{\mathrm{a}}$ \\
\hline Total viable fetus & $8.75 \pm 3.20^{\mathrm{a}}$ & $7.50 \pm 0.57^{\mathrm{ab}}$ & $7.00 \pm 1.4^{\mathrm{ab}}$ & $5.25 \pm 2.21^{\mathrm{b}}$ \\
\hline Total dead fetus & $0.0 \pm 0.0^{\mathrm{a}}$ & $0.0 \pm 0.0^{\mathrm{a}}$ & $0.0 \pm 0.0^{\mathrm{a}}$ & $0.0 \pm 0.0^{\mathrm{a}}$ \\
\hline Fetal weight (g) & $31.45 \pm 2.00^{\mathrm{a}}$ & $30.42 \pm 1.12^{\mathrm{a}}$ & $34.82 \pm 4.15^{\mathrm{a}}$ & $30.58 \pm 2.58^{a}$ \\
\hline Weight of placenta (g) & $6.9 \pm 0.10^{\mathrm{a}}$ & $5.44 \pm 0.55^{b}$ & $6.24 \pm 0.57^{a}$ & $5.37 \pm 0.47^{b}$ \\
\hline Sex-ratio (M/F) & $0.57 \pm 0.11^{\mathrm{a}}$ & $0.52 \pm 0.15^{\mathrm{a}}$ & $0.57 \pm 0.11^{\mathrm{a}}$ & $0.37 \pm 0.28^{\mathrm{a}}$ \\
\hline Fetal length (mm) & $88.95 \pm 4.03^{a}$ & $88.31 \pm 1.60^{\mathrm{a}}$ & $88.51 \pm 1.44^{\mathrm{a}}$ & $87.15 \pm 3.11^{a}$ \\
\hline Fetal head length ( $\mathrm{mm}$ ) & $27.92 \pm 0.3^{\mathrm{a}}$ & $27.29 \pm 0.34^{\mathrm{a}}$ & $27.13 \pm 1.29^{a}$ & $27.31 \pm 2.53^{\mathrm{a}}$ \\
\hline Crown rump length (mm) & $22.64 \pm 1.70^{\mathrm{a}}$ & $21.24 \pm 1.15^{\mathrm{a}}$ & $22.88 \pm 1.79^{a}$ & $21.3 \pm 3.31^{a}$ \\
\hline Fetal tail length (mm) & $12.69 \pm 0.99^{a}$ & $12.66 \pm 0.84^{\mathrm{a}}$ & $11.71 \pm 0.50^{\mathrm{a}}$ & $11.39 \pm 1.61^{a}$ \\
\hline
\end{tabular}

$\mathrm{n}=$ number of rabbit; $(\mathrm{a}, \mathrm{b})$ on the same line, values affected by the same letter are not significantly different; data were expressed as mean \pm standard deviation.

During pregnancy, body weight gain decreased in treated group, which may relate to a growth retardation or reduction of prolificacy index due to CP. A dose dependent decrease of gravid uterine weight, litter weight and size, prolificacy and fertility indices were recorded in CP treated rabbit does as compare to control. Similarly, Fritz and Hess (1971) and Mackler et al. (1975) reported mice and rats treated with $500,1000 \mathrm{mg} / \mathrm{kg}$ and $200,300 \mathrm{mg} / \mathrm{kg}$ BW of CP, respectively. Previous studies reported that $\mathrm{CP}$ could cross the placental barrier and affect embryo/fetal development (Wangikar et al., 2005; Stouten, 2011). Moreover, the reduction of ovaries and placental weights may lead to insufficient progestagen hormone synthesis which is important in maintaining pregnancy development. This may explain the increase of total resorptions recorded in this work. Furthermore, Milhaud (1985) stated that CP residues and metabolites are present in all edible tissues. In the uterine tissues, $C P$ may have caused damage, which prevented implantation, leading to the increase of preimplantation loss. According to El Gendy et al. (2015), CP may also act as an agonist of estrogens, induce a negative feedback of pituitary hormone (LH, FSH, Prolactin) secretion, and so reduce ovogenesis, the number of fetuses and fertility. Such results have been reported with $\mathrm{CP}(200,300 \mathrm{mg} / \mathrm{kg}$ BW) (Mackler et al., 1975).

This study indicated a significantly reduced protein level in the treated group. Moreover, previous studies demonstrated that CP inhibitted protein synthesis by amino acid starvation of an amino acid auxotroph, and by inactivation of temperature-sensitive amino acyl transfer ribonucleic acid synthetase and ribosomal mutations (Klainer and Russel, 1975; Triinu et al., 2009).

\section{Conclusions}

Chloramphenicol at $75 \mathrm{mg} / \mathrm{kg}$ BW affected the embryo/fetus development. It significantly increased the number of pre implantation 
Ngoula Ferdinand et al/Animal Production. 21(1):1-9, 2019

Accredited by Kemenristek Dikti No 32a/E/KPT/2017. ISSN 1411-2027

resorptions and decreased the weight of gravid uterus, the litter weight and size.

\section{References}

Ada K. 2007. Chloramphenicol - Acutetox. $2^{\text {nd }}$ edition, p. 952. W.B. Saunders company. www.acutetox.eu

Bradford MN. 1976. A Rapid And Sensitive Method for The Quantification of Microgram Quantity of Protein-Dye Binding. Analytical Biochemistry, 72: 248-254.https://doi.org/10.1016/0003-2697(76) 90527-3

Dang PK, Saegerman C, Douny C, Dinh TV, Xuan BH, Vu BD, Hong NP, and Scippo ML. First Survey on the Use of Antibiotics in Pig and Poultry Production in the Red River Delta Region of Vietnam. Food and Public Health, 3 (5): 247-256. doi:10.5923/j.fph.20130305.03

El Gendy MM, Kandil AM, Helal MA, and Zahou FM 2015. The Teratogenic Effects of Imatinib Mesylate on Rat Fetuses. Toxicology Reports, 2: 654-663.

https://doi.org/10.1016/j.toxrep.2015.05.001

FAO/WHO. 2012. 75th meeting. Joint FAO/WHO Expert Committee on Food Additives. Residue Evaluation of Certain Veterinary Drugs. Rome, Italy, 8-17. http://www.fao.org/3/a-at872e.pdf

FAO/WHO. 2012. Food Standards Program Codex Committee on Residues of Veterinary Drugs in Foods. Risk Management Recommendations For Veterinary Drugs for Which No ADI And/or MRL Has Been Recommended By JECFA Due to Specific Human Health Concerns: chloramphe nicol. http://www. fao.org /tempref /codex/ Meetings/CCRVDF/ccrvdf19/CRDs/RV19_CRD12e .pdfFritzH.

Hess R. 1971. Effect of Chloramphenicol on The Prenatal Development of Rats, Mice, and Rabbits. Toxicology and Applied Pharmacology, 19 (4): 667-674. https://doi.org/10.1016/0041008X(71) 90298-5.

Gornal AG, Bardwil GS, and David M.M. 1949. Determination of Serum Proteins by Mean of Biuret Reactions, Journal of Biological Chemistry, 177: 751-766. http://www.jbc.org/ content/177 /2/751.citation

Ian P, Casewell M, Cox T, De Groot B, Friis C, Jones R, Nightingale C, Preston R, and Waddell J. 2004. Does The Use of Antibiotics in Food Animals Pose
A Risk to Human Health? A Critical Review Of Published Data. Journal of Antimicrobial Chemotherapy, $53 \quad$ (1): 28-52. DOI:10.1093/jac/dkg483

Jeong-Sup $\mathrm{H}$, Wook-Joon $\mathrm{Y}$, You-Seok K, Jin- Sik C, Myeong-kyu P, Soo-min C, Hee Y, Hee-jung C, and Ho-chul S. 2012. Development of A Semen Preparation Method for Artificial Insemination in Rabbit. Journal of animal and veterinary advances, 11(6): 712-718. DOI: 10.3923/javaa. 2012.712.718

Klainer AS and Russell RRB. 1975. Effect of The Inhibition of Protein Synthesis on The Escherichia Coli Cell Envelope. Antimicrobial Agents and Chemotherapy, 7(1): 115. http://www.ncbi. nlm. nih.gov/pmc/journals/82.

Mackler B, Grace R, Tippit DF, Lemire RJ, Shepard TH, and Kelley VC. 1975. Studies of The Development of Congenital Anomalies In Rats. III. Effects of Inhibition of Mitochondrial Energy Systems on Embryonic Development. Teratology, 27; 12(3): 291-296. DOI: 10.1002/tera.1420120311

Milhaud G. 1985. Les Résidus De Chloramphénicol Et Leur Toxicité. Annales De Recherches Vétérinaires, INRA Editions, 1985, 16 (2), pp.132148. https://hal.archives-ouvertes.fr/hal-009015 63/document.

Nouws JFM, Vree TB, Holtkamp J, Baakman M, Driessens F, and Guelen PJM. 1986. Pharmacokinetic, Residue and Irritation Aspects of Chloramphenicol Sodium Succinate and A Chloramphenicol Base Formulation Following Intramuscular Administration to Ruminants. Veterinary Quarterly, 8: 224-232. DOI:10.1080/ 01652176.1986 .9694046$.

Saba AB, Davies O, Oyeyemi MO, and Ajala O. 2000. The Toxic Effects of Prolonged Administration of Chloramphenicol on The Liver And Kidney of Rats. African Journal of Biomedical Research, 3: 133 - 137. http//: www.ajbr98.com

Stouten JTJ. 2011. Chloramphenicol: Evaluation of The Effects on Reproduction, Recommendation for Classification. Health Council of the Netherlands. https:www//healthcouncil.nl

Triinu S, Lauri $\mathrm{P}$, Liqun $\mathrm{X}$, Alexander $\mathrm{M}$, Jaanus $\mathrm{R}$, and Tanel T. 2009. Erythromycin- and Chloramphenicol - induced ribosomal assembly defects are secondary effects of protein synthesis inhibition. Antimicrobial Agents and 
Ngoula Ferdinand et al/Animal Production. 21(1):1-9, 2019

Accredited by Kemenristek Dikti No 32a/E/KPT/2017. ISSN 1411-2027

Chemotherapy, 53(2): 563-571. DOI: 10.1128/AAC.00870-08.

Waalkens-berendsen DH, Verhagen FJJ, and Bar A. 1998. Embryotoxity And Teratogenicity Study

Wollenberger L, Halling-Sorensen B, and Kusk KO. 2000. Acute and Chronic Toxicity of Veterinary with Gamma Cyclodextrin in Rats. Regulatory Toxicology And Pharmacology. 27: 166-177. DOI:10.1006/rtph.1998.1221.

Wangikar PB, Dwivedi P, Sinha N, Sharma AK, and Telang AG. 2005. Effects of Aflatoxin B1 on Embryo Fetal Development in Rabbits. Food and Chemical Toxicology, 43: 607-615. https: //doi.org /10.1016/j.fct.2005.01.004 Antibiotics to Daphnia Magna. Chemosphere, 40(7): 723-30. https://doi.org/10.1016/S00456535(99)00443-9

Yamada T, Hara M, Ohba $Y$, Inoue T, and Ohno. 1985. Studies on Implantation Traces in Rats. II. Staining of Cleared Uteri, Formation and Distribution of Implantation Traces. Jikken Dobutsu., 34: 249-260.https://www.ncbi.nlm. nih.gov/pubmed/2415372. 